\title{
Strategi Badan Pengelolaan Air Bersih (BPAB) dalam Mempertahankan Eksistensi (Studi Kasus: Nagari Sungai Sariak Lumpo Kecamatan IV Jurai Kabupaten Pesisir Selatan
}

\author{
Muklis Muklis ${ }^{1}$, Nora Susilawati ${ }^{2}$ \\ 1,2 Universitas Negeri Padang \\ Email:vf.muklis@gmai.com ${ }^{2}$ susilawatinora@gmail.com
}

\begin{abstract}
Abstrak
Penelitian ini bertujuan untuk menjelaskan strategi yang dilakukan oleh BPAB untuk mempertahankan eksistensi. Terlihat bahwasanya sumber air bersih BPAB ini telah berdiri dari tahun 2003 yang dibangun secara swadaya dalam bentuk kerjasama oleh mayarakat Nagari Sungai Sariak Lumpo. BPAB telah menjadi aset Nagari Sungai Sarik Lumpo, singga BPAB harus bisa eksis dan berkembang di tengah-tengah masyarakat. Untuk menganalisis permasalahan penelitian ini, penulis menggunakan teori structural fungsional Talcott Parsons. Dalam teori terdapat empat unsur penting untuk melaksanakan sistem agar tetap bertahan, keempat sistem itu iyalah Adaptation (Adaptasi), Goal Attainment (Pencapaian Tujuan), Integration (Penyatuan), Latency (Pemeliharaan Pola). Metode yang digunakan ialah pendekatan kualitatif dengan tipe studi kasus serta teknik pemilihan informan adalah Teknik purposive sampling. Pengumpulan data dilakukan dengan cara observasi, wawancara, dokumentasi denga teknik analisis data interaktif dari Miles dan Huberman. Hasil penelitian mengenai strategi yang digunakan BPAB dalam mempertahankan eksistensi, secara internal: (1). Kekompakan antara pengurus (2). Pengurus menjalankan peranya untuk menjaga kualitas air (3). Pengurus merespon dengan cepat masalah atau keluhan pelanggan. Secara eksternal: (1). Menganggap pelanggan sebagai keluarga.
\end{abstract}

Kata Kunci: BPAB, Eksistensi, Strategi

\section{Abstract}

This study aims to explain the strategy undertaken by BPAB to maintain its existence. It can be seen that this BPAB clean water source has been established since 2003 which was built independently in the form of a collaboration by the people of Nagari Sungai Sariak Lumpo. BPAB has become an asset for Nagari Sungai Sarik Lumpo, so BPAB must be able to exist and develop in the midst of society. To analyze the problem of this research, the author uses the structural functional theory of Talcott Parsons. In theory, there are four important elements to implement the system in order to survive, the four systems are Adaptation, Goal Attainment, Integration, Latency. The method used is a qualitative approach with the type of case study and the informant selection technique is purposive sampling technique. Data was collected by means of observation, interviews, documentation with interactive data analysis techniques from Miles and Huberman. The results of the research on the strategies used by $B P A B$ in maintaining the existence, internally: (1). Cohesiveness between the administrators (2). Management carries out its role to maintain water quality (3). Management responds quickly to customer problems or complaints. Externally: (1). Treat customers as family.

Keywords: BPAB, Existence, Strategy

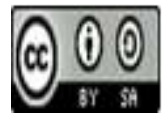

Received: October 11, $2021 \quad$ Revised: December 23, 2021 Available Online: December 24, 2021 
Muklis Muklis, Nora Susilawati Strategi Badan Pengelolaan Air Bersih (BPAB) dalam Mempertahankan Pelanggan Di Nagari Sungai Sarik Lumpo, Kecamatan IV Jurai, Kabupaten Pesisir Selatan

\section{Pendahuluan}

Air bersih merupakan salah satu kebutuhan yang sangat penting sekali bagi manusia. Dalam menjalankan aktivitas sehari-hari, dan manusia tidak akan terlepas dari air, karena air adalah kebutuhan primer manusia dan juga guna untuk mempertahankan kelangsungan hidupnya. Sesuai yang disampaikan oleh Mentri Kesehatan R.I No. 416/MENKES/PER/IX/1990 tentang persyaratan kualitas air bersih, air yang memenuhi syarat kesehatan yaitu jernih, tidak berbau, tidak berasa, tidak bewarna, tidak mengandung kuman dan zat-zat berbahaya (Simanjuntak et al., 2020). Berdasarkan peraturan Pemerintah Republik Indonesia Nomor 122 Tahun 2015 tentang sistem penyadiaan air minum, yang dimaksud air baku adalah air yang berasal dari sumber air permukaan, air tanah, air hujan dan air laut yang memenuhi mutu tertentu untuk air minum untuk dimanfaatkan dalam keseharian (Yustika Kusumawardani \& Astuti, 2018).

Sumber air yang berada di Kecamatan IV Jurai telah banyak tercemar dan tidak memenuhi syarat untuk kualitas air bersih seperti tidak jernih, berbau dan mengandung kuman. Ini diakibatkan oleh pembuangan limbah rumah tangga, sampah-sampah yang dibuang kesungai, sehingga air sungai tidak lagi bisa dimanfaatkan sebagai sumber air bersih bagi masyarakat.

Sebelum adanya BPAB, Masyarakat Nagari Sungai Sariak Lumpo menggunakan sungai yang mengalir dekat rumah sebagai sumber air bersih utama untuk keperluan sehari-hari. Air sungai yang mengalir di Nagari Sungai Sarik Lumpo ini memiliki hulu yang jauh, dan juga sungai ini telah melewati beberapa nagari di Kecamatan IV Jurai, sehingga nagari yang di lalui oleh sungai ini memanfaatkannya sebagai sumber air bersih. Selepas dari itu ada juga beberapa individu yang menggunakan sumur sebagai sumber air bersih utama mereka.

Melihat situasi masyarakat yang menggunakan sungai sebagai sumber air bersih untuk keperluan sehari-hari, maka di tahun 2000 datanglah suatu lembaga yaitu LP2N yang ingin membantu masyarakat Nagari Sungai Sarik Lumpo untuk memanfaatkan sumber air yang ada. Sehingga hal demikian disambut baik oleh masyarakat Nagari Sungai Sarik Lumpo, selanjutnya di tahun 2003 di mulailah pembangunan sumber air bersih ini yang bepusat di pegunungan Nagari Sungai Sarik Lumpo.

Pembangunan sumber air bersih ini tidak hanya melibatkan LP2N akan tetapi masyarakat Nagari Sungai Sarik Lumpo juga ikut andil berpartisipasi dan mereka saling bekerja sama. Motivasi juga dibutuhkan untuk mengarahkan daya dan potensi agar bisa bekerja sama untuk menyelesaikan tujuan yang ingin dicapai (Komunikasi et al., 1973). Dalam membangun sumber air bersih ini, dan setelah pembangunan sumber air bersih ini selesai maka masyarakat Nagari Sungai Sarik Lumpo secara swadaya memberi nama sumber air bersih ini dengan sebutan Badan Pengelolaan Air Bersih yang disingkat dengan BPAB. Setelah adanya nama untuk sebutan sumber air bersih ini dan selanjutnya

masyarakat secara swadaya membentuk suatu organisasi yang akan mengurus sumber air bersih ini untuk kedepanya.

Setelah terbentuknya organisasi yang akan mengurus sumber air bersih BPAB dan di dalamnya ada dewan pengurus seperti ketua, bendahara, sekretaris, petugas teknisi lapangan dan petugas pencatat data pembayaran setiap bulanya. Dalam hal ini organisasi adalah hubungan yang terstruktur yang mengkoordinasi suatu usaha kelompok orang untuk mencapai tujuan tertentu yang ingin dicapai secara bersama (Sumatera, n.d.). Semua komponen di dalam organisasi kepengurusan BPAB ini saling bekerja sama untuk melakukan peran dan tugas masing-masing yang telah diamanahkan oleh masyarakat kepada mereka. Selanjutnya peneliti 
Muklis Muklis, Nora Susilawati Strategi Badan Pengelolaan Air Bersih (BPAB) dalam Mempertahankan Pelanggan Di Nagari Sungai Sarik Lumpo, Kecamatan IV Jurai, Kabupaten Pesisir Selatan

melakukan wawancara dengan salah seorang petugas BPAB yang menjelaskan bahwasanya, BPAB ini sudah berdiri sejak tahun 2003 yang dibentuk secara swadaya oleh masyarakat Nagari Sungai Sariak Lumpo, dan apabila individu ingin menggunakan layanan BPAB ini harus membayar dulu sebanyak Rp 500.000,- untuk Nagari Sungai Sarik Lumpo, dan untuk di luar Nagari Sungai Sarik Lumpo masyarakat harus membayar sebanyak Rp 800.000,- yang mana uang ini dipergunakan untuk keperluan pengaliran air seperti buat beli pipa, kran dan keperluan lainya. Sedangkan untuk perkubiknya pengguna sumber air berih BPAB harus membayar sebanyak Rp 500,- dan uang ini akan ditagih oleh petugas setiap bulanya.

Berdasarkan penjelasan informan terlihat bahwasanya berdirinya BPAB tidak terlepas dari peran penting masyarakat karena masyarakat secara swadaya bersama-sama membangun sumber air bersih ini, dan setelah berdiri masyarakat boleh menggunakan sumber air bersih ini dengan syarat harus membayar, dan biayanya pun tidak begitu besar, sehingga masyarakat di Nagari Sungai Sarik Lumpo seluruhnya menggunakan sumber air bersih BPAB ini bahkan masyarakat di luar Nagari Sungai Sarik Lumpo pun mau membayar agar bisa menggunakan sumber air bersih ini. Sumber air bersih BPAB yang dibangun secara swadaya dengan cara kerja sama oleh masyarakat Nagari Sungai Sarik Lumpo memberikan maanfaat bagitu besar bagi masyarakat seperti kemudahan dalam pemanfaatan sumber air bersih dan harga yang didapatkan juga terjangkau, hal ini membuat sumber air bersih BPAB selalu di percaya oleh masyarakat Nagari Sungai Sarik Lumpo sehingga bisa eksis dan bertahan sampai sekarang. Hal ini tidak akan terlepas dari peran penting pengurus yang mengelola sumber air bersih ini dan juga masyarakat Nagari Sungai Sarik Lumpo sebagai pendukung keberhasilan sumber air bersih ini. Tujuan yang diharapkan dari penelitian ini adalah dapat menjelaskan strategi yang dilakukan BPAB dalam mempertahankan eksistensi

Beberapa hasil penelitian tekait dengan penelitian yang penyaji lakukan adalah penelitian yang di lakukan oleh Novita dkk (Novita, 2017) sejalan dengan itu (Kornita \& Riau, 2020) juga meneliti hal yang sama sehingga butuh sebuah analisis dan formulasi (perumusan) strategi terkait dengan ketersedian air di masyarakat Ketika ada krisis. Sejalan dengan ini penelitian lain juga di lakukan oleh (Winarno et al., 2011) bahwa dalam mengelola air itu secara baik maka dibutuhkan suatu lembaga untuk mencapai keberlanjutan pemanfaatan air bersih dalam masyarakat. Berdasarkan penelitian-penelitian dan artikel-artikel yang terkait dengan bagaimana pengelolaan air bersih bagi masyarakat dilihat bahwa perlunya suatu analisis dan formulasi strategis terkait ketersediaan air bersih ketika krisis serta perlunya suatu peningkatan pelayanan penyedian air bersih, selanjutnya diperlukan juga suatu strategi pengawasan di dalam sistem penyediaan air bersih untuk masyarakat.

Namun dari sebagian banyak penelitian-penelitian tersebut berbeda dengan peneliti teliti di lihat penelitian diatas lebih melihat suatu analisis dan formulasi (perumusan), peningkatan pelayanan serta pengawasan di dalam penyedian air bersih, disini peneliti lebih melihat strategi pengelolaan air bersih oleh BPAB dalam mempertahankan eksistensi, sehingga inilah yang menjadi ketertarikan peneliti untuk melakukan penelitian yang berhubungan dengan Strategi Badan Pengelolaan Air Bersih (BPAB) dalam Mempertahankan Eksistensi (Studi Kasus: Nagari Sungai Sariak Lumpo, Kecamatan IV Jurai, Kabupaten Pesisir Selatan). Dalam pemaparan yang sudah peneliti sampaikan sebelum peneliti tertarik untuk melakukan penelitian tentang strategi (BPAB) dalam mempertahankan eksistensi. Penelitian ini penting untuk diteliti karena BPAB yang sudah berdiri sejak tahun 2003 dan telah menjadi aset Nagari Sungai Sariak Lumpo yang harus di jaga dan dipertahankan sehingga bisa eksis dan berkembang di tengah-tengah masyarakat. 
Muklis Muklis, Nora Susilawati Strategi Badan Pengelolaan Air Bersih (BPAB) dalam Mempertahankan Pelanggan Di Nagari Sungai Sarik Lumpo, Kecamatan IV Jurai, Kabupaten Pesisir Selatan

\section{Metode Penelitian}

Penelitian ini menggunakan pendekatan kualitatif. Tipe dari penelitian yang dilakukan oleh peneliti adalah studi kasus, dengan tipe desain kasus tunggal terjalin dimana unit pusatnya adalah organisasi sebagai suatu keseluruhan dan unit terkecilnya adalah anggota perorangan, dan beberapa unit perantara yang dipandang penting. Pendekatan kualitatif yaitu suatu pendekatan yang berusaha menjelaskan realita sosial yang ingin diteliti secara mendalam menggunakan data kualitatif berupa kata-kata, abstraksi, observasi dan pernyataan (Moeleong, 2006). Miles dan Huberman (1984) mengemukakan bahwa aktivitas dalam analisis data kualitatif dilakukan secara interaktif dan berlangsung secara terus-menerus sampai tuntas, sehingga datanya sudah jenuh, analisis data kualitatif memberikan hasil penelitian untuk memperoleh gambaran terhadap proses yang diteliti dan juga menganalisis makna yang ada di balik informasi, data dan proses tersebu (Sugiyono, 2007). Lokasi penelitian ini dilakukan di Nagari Sungai Sariak Lumpo, Kecamatan IV Jurai, Kabupaten Pesisir Selatan. Metode dalam pemilihan informan menggunakan teknik purposive sampling, yaitu subyek penelitian ditentukan berdasarkan pertimbangan-pertimbangan tertentu yang diambil berdasarkan tujuan penelitian. Teknik purposive sampling disini dipakai agar peneliti mendapat kemudahan memperoleh informan. Tindakan purposive individu memerlukan optimalisasi. Sebagai teori yang banyak dipengaruhi oleh ekonomi maka prinsip optimalisasi ini hampir sama dengan prinsip ekonomi (Arsita et al., n.d.). Informan dalam penelitian ini sebanyak 7 orang yaitu 1 orang pengawas, 1 orang pengurus BPAB, wali nagari Sungai Sarik Lumpo, dan masyarakat Sungai Sarik Lumpo yang di bedakan atas beberapa golongan pekerjaan seperti, 1 orang golongan atas yaitu guru, 1 orang golongan menengah yaitu pedagang, dan 1 orang golongan bawah yaitu pekerja buruh.

\section{Hasil dan Pembahasan}

\section{Hasil Penelitian}

Berdasarkan penelitian yang peneliti lakukan di Nagari Sungai Sariak Lumpo, Kecamatan IV Jurai, Kabupaten Pesisir Selatan dari tanggal 25 September sampai 25 Agustus 2021 mengenai strategi Badan Pengelolan Air Bersih (BPAB) dalam mempertahankan eksistensi, maka perlunya suatu strategi untuk dalam pengelolaan BPAB untuk bisa selalu eksis dan berkembang di tengah-tengah masyarakat. Berikut merupakan beberapa pengertian yang dikemukakan oleh beberapa orang ahli mengenai strategi, Steiner dan Milner mengemukakan strategi adalah penetapan misi perusahaan, penetapan sasaran organisasi dengan meningkatkan kekuatan eksternal dan internal, perumusan kebijakan dan implementasi secara tepat sehingga tujuan dan sasaran utama organisasi akan tercapai. Sedangkan menurut Johnson dan Scholes yang dimaksud strategi ialah arah dan ruang lingkup dari sebuah organisasi atau lembaga dalam jangka panjang, yang mencapai keuntungan melalui konfigurasi dari sumber daya dalam lingkungan yang menantang, demi memenuhi kebutuhan pasar dan suatu kepentingan (Mubarok, 2017), selanjutnya menurut Crow strategi adalah hal sehubungan dengan menetapkan arah bagi perusaahan serta dapat memberikan keuntungan yang baik untuk membantu memenangkan persaingan dipasar (Sugiarto et al., 2016). Sehingga dapat disimpulkan bahwa strategi adalah suatu perencanaan, atau gagasan yang mampu mencapai sebuah tujuan dalam jangka waktu tertentu. Berikut merupakan strategi yang dilakukan oleh BPAB untuk mempertahankan eksistensi berdasarkan wawancara dan observasi peneliti di lapangan: 
Muklis Muklis, Nora Susilawati

Strategi Badan Pengelolaan Air Bersih (BPAB) dalam Mempertahankan

Pelanggan Di Nagari Sungai Sarik Lumpo, Kecamatan IV Jurai, Kabupaten Pesisir Selatan

\section{Internal}

\section{Kekompakan Antara pengurus}

Dalam mengelola sumber air berih BPAB ini pengurus menjalankan peran dan fungsinya masing-masing, di dalam kepengurusan ini terdapat ketua pengawas, pengawas 1 dan pengawas 2, ketua pengurus, sekretaris, bendahara, teknisi lapangan dan teknisi pencatatan penagihan uang bulanan. Dalam organisasi kepengurusan BPAB ini semua komponen yang terdapat di dalamnya menjalankan perannya dengan baik serta hubungan baik yang di tunjukan oleh kepengurusan kepada para pelangganya baik di Nagari Sungai Sarik lumpo maupun pelanggan diluar Nagari Sungai Sarik Lumpo.

Kekompakan didalam kepengurusan BPAB ini memang sudah terlihat dari cara kerja yang dilakukan oleh para pengurus, dan disini peran penting dari ketua pengawas dalam mengorganisir kinerja dari para anggotanya yang mengakibatkan anggotanya menjalankan peran dan fungsinya masing-masing di dalam kepengurusan. Ketua pengawas adalah orang yang disegani oleh masyarakat begitu juga oleh anggota kepengurusn BPAB ini, karena ketua pengawas sendiri seorang tokoh didalam masyarakat Nagari Sungai Sarik Lumpo.

Kekompakan dalam kepengurusan membawa dampak positif bagi BPAB sendiri yang terlihat dari para pelanggan $\mathrm{BPAB}$ yang selalu mengalami peningkatan jumlah pelanggan sehingga BPAB bisa eksis dan berkembang sampai sekarang. Dalam hal ini peneliti melalakukan wawancara awal kepada ketua pengawas BPAB untuk menggali lebih dalam mengenai cara untuk mempertahankan kekompakan antara pengurus. Wawancara pertama ini peneliti lakukan kepada Bapak Agustiar sebagai ketua pengawas BPAB.

“...Bapak sebagai ketua pengawas BPAB mengenai baik seluruh anggota. Dan kami mengutamakan koordinasi baik serta kerjasama untuk membangun kedekatan dan memudahkan didalam penyelesaian pekerjaan, ini semua kami lakukan dalam kepengurusan untuk memajukan sumber air bersih ini..." (Wawancara tanggal 25 Agustus 2021).

Berdasarkan yang disampaikan oleh Bapak Agustiar (61 Tahun) sebagai ketua pengawas ini mengambarkan peran penting dari seorang pemimpin terhadap anggotanya, dan terbukti dengan kekompakan yang dilakukan oleh pengurus ini akan membawa dampak positif bagi $\mathrm{BPAB}$ untuk kedepanya sehingga $\mathrm{BPAB}$ ini bisa eksis dan berkembang di tengah-tengan masyarakat sampai sekarang.

\section{Pengurus Menjalankan Perannya Untuk Menjaga Kualitas Air}

Menurut Sondang peran adalah tempat yang ditentukan untuk menduduki oleh sesorang dalam proses pencapaian tujuan (Ii \& Teoritis, 2003). Pengurus menjalankan tugasnya untuk selalu mengawasi dan memantau apabila terjadi pencemaran air ataupun penyumbatan yang disebabkan oleh sampah sehingga air bisa terjaga dan higienis. Dalam hal ini pengurus menjalankan kontrol dengan cara, pengurus yang telah dibentuk selanjutnya berbagi tugas dimana mereka menjalankan peranya masing-masing. Sehinga mereka berkerja sama dan menjadi satu kesatuan di dalam pekerjaan.

Dalam hal ini pengurus juga melibatkan masyarakat di dalam bekerja sama untuk menjaga kualitas air agar selalu higienis, misalnya apabila terjadi gangguan terhadap bendungan air yang disebabkan oleh pohon tumbang, maka dengan ini petugas berkomunikasi kepada masyarakat untuk bekerja sama dalam menyelesaikan masalah tersebut, dengan kontrol 
Muklis Muklis, Nora Susilawati Strategi Badan Pengelolaan Air Bersih (BPAB) dalam Mempertahankan Pelanggan Di Nagari Sungai Sarik Lumpo, Kecamatan IV Jurai, Kabupaten Pesisir Selatan

ini apabila terjadi kerusakan atau pencemaran terhadap air bersih maka masyarakat akan cepat melapor kepada petugas.

Petugas menjalankan peran serta kontrol dilakukan untuk memberikan yang terbaik bagi pelanggannya. Menjaga kualitas air agar selalu higienis dan tidak tercemar. Berikut merupakan wawancara peneliti dengan pengawas BPAB, informan ini Bernama Bapak Agustiar:

“...Kami sebagai pengawas BPAB menginginkan yang terbaik untuk pelanggan atau pengguna dari sumber air berish ini, karna setelah pelayanan yang baik maka kami akan menjaga kualiatas air bersih ini, dengan cara adanya petugas yang bertugas dalam menjalankan peranya untuk memantau atau mengawasi kualitas air bersih $\mathrm{BPAB}$, dan petugas yang telah diberikan peran untuk selalu rutin memeriksa dari hulu air bersih ini hingga sampai ke bendunganya, karena sumber air bersih ini bersumber dari gunung dan dilakukan secara manual tentu aka ada banyak masalah-masalah yang terjadi yang membuat tercemarnya air bersih dan mengakibatkan kualitas air bersih BPAB menjadi berkurang, dan hal ini petugas selalu siap manjalankan peran utuk selalu menjaga kualitas air..."(Wawancara tanggal 25 Agustus 2021).

Wawancara di atas menjelaskan bahwa perlunya strategi dan perencanaan yang baik dalam menjalan sesuatu, dan terlihat dari penjelasan yang di sampaikan oleh informan yang berprofesi sebagai pengawas BPAB, yang mana setelah pelayanan yang baik maka harus bisa menjalankan peranya dengan baik untuk menjaga kualitas air. Dalam hal ini pengurus menjalankan peranya serta kontrol yang dilakukan. Petugas bekerja sama dengan masyarakat apabila air bersih ini mengalami gangguan pada sungai atau bendungan air BPAB. Ini bertujuan untuk meningkatkan kepercayaan pelanggan kepada BPAB sebagai sumber air bersih utama dan setia kepada BPAB, kualitas air yang baik akan membuat masyarakat sebagai pelanggan $\mathrm{BPAB}$ merasa aman di dalam mengkonsumsi sumber air bersih yang telah terjamin kualitasnya, dan sumber air bersih BPAB sudah ada sertifikat yang mengatakan kelayakan untuk dikonsumsi.

Berdasarkan observasi yang peneliti lakukan pada Kamis tanggal 03 september 2021, peneliti langsung pergi ke lokasi dimana tempat penyaringan atau bendungan awal di sungai yang berada di pegunungan, peneliti pergi diwaktu pagi hari dan ditemani oleh seorang teman, dan perjalanya menuju lokasi tidaklah mudah karena adanya beberapa tanjakan perbukitan yang harus dilewati dan jalan menuju lokasi yang masih menggunakan jalan setapak yang biasa dilewati oleh petani karet yang ingin mengambil getah karet, pada saat itu kondisi cuaca yang cerah dan menjadikan perjalanan peneliti tidak ada hambatan, dan setelah peneliti sampai di lokasi peneliti melihat air sungai sebagai sumber air bersih BPAB ini sangat bersih dan jernih, dan BPAB memanfaatkan sungai ini sebagai sumber airnnya, dan terlihat ada bendungan air yang dibuat secara manual oleh petugas atau masyarakat secara bersama-sama dahulu disaat awal berdirinya BPAB ini, dan ada saringan menuju pipa penampungan air yang selanjutnya menuju lokasi penampungan air bersih ini, berikut dokumentasi saat observasi peneliti dilapangan.

Selanjutnya peneliti melanjutkan wawancara dengan ketua petugas BPAB, yaitu Drs. Jasli, dari keterangan informan bahwasanya tidak jauh berbeda dari apa yang disampaikan oleh informan peneliti yaitu pengurus $\mathrm{BPAB}$, yang mengatakan perlunya suatu strategi didalam mengelola BPAB ini, dan setelah melakukan pelayanan yang baik dan selanjutnya hal yang dilakukan BPAB yaitu pengurus menjalankan peranya untuk menjaga kualitas air, namu informan lebih menekankan bahwasanya kualitas yang diberikan BPAB sejak awal berdirinya 
Muklis Muklis, Nora Susilawati Strategi Badan Pengelolaan Air Bersih (BPAB) dalam Mempertahankan Pelanggan Di Nagari Sungai Sarik Lumpo, Kecamatan IV Jurai, Kabupaten Pesisir Selatan

dan sampai saat ini belum ada keluhan atau akibat negative dari penggunaan sumber air bersih BPAB ini.

Peran yang dijalankan petugas untuk menjaga mutu kualitas air bersih yang dilakukan oleh petugas BPAB sudah sangat baik dan terbukti tidak adanya keluhan pelanggan BPAB mengenai kualitas air yang dibuktikan dengan tidak adanya laporan dari pelanggan mengenai akibat buruk yang ditimbulkan dari pemanfaatan sumber air bersih BPAB dalam keseharian, mulai dari untuk di konsumsi atau sebagainya.

Berdasarkan penjelsan yang disampaikan oleh Bapak Alirman S.Pd bahwasanya petugas BPAB telah menjalankan peranya dengan baik dalam kepengurusan, terbukti dengan kualitas air saat ini sangat bagus dan cocok untuk dijadikan sumber air bersih dalam keseharian, karena kualitas dari air bersih BPAB ini sangatlah membantu masyarakat didalam pemanfaatan sumber air bersih, untuk itu BPAB harus mampu memberikan yang terbaik untuk masyarakat sebagai pelangganya.

Menjalankan peran sesui yang telah diamanahkan oleh masyarakat sangatlah penting, terutama untuk menjaga kualitas air merupakan hal yang harus dilakukan karena jika kualitas tidak dapat dipastikan baik maka akan banyak dampak yang ditimbulkan, seperti membawa penyakit, untuk itu BPAB selalu menjaga kualitas air bersihnya sebelum disalurkan ke rumahrumah masyarakat sebagai pelanggan BPAB yang berada di Nagari Sungai Sarik Lumpo.

\section{Merespon Cepat Masalah atau Keluhan Pelanggan}

Respon cepat yang dilakukan oleh petugas BPAB terhadap masalah atau keluhan pelanggan adalah salah satu prioritas yang diterapkan BPAB di dalam memberikan pelayanan untuk pelangganya, respon sendiri bisa dimaksud tingkah laku atau sikap yang berwujud baik yang mana perubahan sikap dapat menunjukan respon seseorang terhadap objek-objek tertentu seperti perubahan lingkungan atau situasi lain (Nurrohman et al., 2015). Dalam hal ini petugas merespon keluhan atau masalah pelanggan paling cepat dalam waktu 15 menit, dan disaat petugas lagi subuk melakukan aktifitas lain maka waktu yang perlu dilakukan untuk pergi ke rumah pelanggan yaitu berkisar antara 1 sampai 3 jam tegantung situasi dan kondisi.

Respon cepat ini adalah salah satu strategi yang diterapkan oleh BPAB di dalam meningkatkan kualitas pelayanan $\mathrm{BPAB}$, karena apabila petugas merespon dengan cepat setiap permasalahan pelanggan, maka pelanggan akan merasa senang serta merasa mendapatkan pelayanan yang sangat baik sehingga mereka betah menggunakan sumber air bersih BPAB.

Berdasarkan hasil wawancara bersama Bapak Agustiar mengatakan bahwa perlunya suatu respon cepat untuk menanggapi permasalahan atau keluhan pelanggan, yang bertujuan agar pelanggan merasa senang karena mendapatkan pelayanan yang sangat baik dari para petugas BPAB, dan respon cepat ini menjadikan salah satu strategi yang diterapkan oleh BPAB dalam mengelola kebutuhan air bersih masyarakat di Nagari Sungai Sarik Lumpo.

Melakukan respon yang baik terhadap sesuatu permasalahan atau keluhan merupkan hal yang harus dilakukan guna meningkatkan kepuasan pelanggan didalam menikmati produk yang diberikan, oleh karena itu strategi yang tepat dan di terapkan oleh BPAB adalah respon cepat setiap permasalahan atau keluhan pelanggannya, karena pelanggan BPAB ini merupakan bagian atau keluarga dari BPAB yang harus mendapatkan suatu pelayanan sebaik mungkin. Berikutnya peneliti melakukan wawancara dengan pelanggan BPAB, apakah BPAB telah menerapkan respon terhadap permasalahan atau keluhan dari pelangganya.

Berdasarkan hasil wawancara menunjukan suatu kepuasan tersendiri kepada BPAB sebagai pengelola kebutuhan air bersih masyarakat, karena BPAB memberikan pelayanan yang sangat baik yang dibuktikan dengan merespon dengan cepat setiap permasalahan yang dialami 
Muklis Muklis, Nora Susilawati Strategi Badan Pengelolaan Air Bersih (BPAB) dalam Mempertahankan Pelanggan Di Nagari Sungai Sarik Lumpo, Kecamatan IV Jurai, Kabupaten Pesisir Selatan

oleh pelangganya dengan sikap ramah, hal tersebut dapat terlihat dari beberapa informan yang peneliti wawancara bahwasanya strategi BPAB untuk melakukan respon cepat terhadap permasalahan yang dihadapi pelangganya sudah cukup baik.

Di dalam menjalankan suatu trategi diperlukan suatu kerja sama tim yang kompak di dalam mengelola untuk mencapai tujuan yang dibuat, dalam hal ini BPAB Sungai Sarik Lumpo membuat suatu strategi yang bertujuan untuk memberikan kepuasan kepada pelangganya, yang mana BPAB berharap agar pelangganya akan selalu mempercayakan sumber air bersih mereka kepada BPAB untuk seterusnya. Dalam hal ini peneliti melakukan wawancara dengan tokoh masyarakat yaitu Wali Nagari Sungai Sarik Lumpo, dalam hal ini diwakilkan langsung kepada Sekretaris Wali Nagari Sungai Sarik Lumpo karena pada hari itu Wali Nagari tidak ada di tempat dikarenakan kesibukan, maka atas perintah Bapak Edi Amanto sebagai Wali Nagri Sungai Sarik Lumpo untuk digantikan oleh sekretarisnya, dan wawancara ini dilakukan pada hari rabu tanggal 8 September 2021 yang bertempat di Kantor Wali Nagari Sungai Sarik Lumpo, dan wawancara ini dilakukan dari pukul pukul 09.00-10.00 WIB. Wawancara dilakukan didalam kantor Wali. Dalam wawancara ini peneliti dibantu oleh seorang teman peneliti yang membantu dalam mengatur dokumentasi. Setelah perkenalan di awal pertemuan, yang mana Ibuk Hastin Media Putri berumur (44 tahun). Ibuk Hastin selaku sekretaris Wali Nagari Sungai Sarik Lumpo sudah menjabat selama dua priode berturut-turut, begitu juga dengan Bapak Edi Amanto sebagai Wali Nagari Sungai Sarik Lumpo yang sudah menjabat selama dua priode berturut-turut.

Berikut merupakan wawancara peneliti dengan Ibuk Hastin Sebagai sekretaris Wali Nagari Sungai Sarik Lumpo mengenai apakah strategi yang dijalankan oleh BPAB untuk kepuasan pelanggan berdasarkan penjelasan yang disampaikan oleh pengawas dan pengurus telah terlaksana dengan baik penyebab seluruh Masyarakat Nagari Sungai Sarik Lumpo memilih atau menggunakan BPAB serta peran penting BPAB untuk nagari:

“...Strategi yang diterpakan oleh BPAB kami rasa telah berjalan sebagai mana mesti yang diharapkan dan masyarakat merasa puas denga napa yang diberikan BPAB sejauh ini, dan BPAB sendiri merupkan suatu aset nagari, terlebih lagi BPAB ini tidak membebani masyarakat dari segi biaya yang harus dikeluarkan oleh masyarakat dengan demikian seluruh masyarakat lebih memilih BPAB dibandingan sumber air bersih lain. BPAB sendiri memiliki peran penting untuk Nagari Sungai Sarik karena BPAB hadir untuk memudahkan masyarakat dari segi sumber air bersih yang berfungsi untuk kebutuan sehari-hari, terlebih lagi BPAB tidak memberatkan masyarakat dari segi pembiayaanya, dan BPAB sendiri berkontribusi didalam pembangunan nagari, seperti BPAB memberikan sumbanganya terhadap pembangunan masjid yang ada di Sungai Sarik Lumpo, dan juga BPAB bertanggung jawab terhadap penerangan lampu yang ada disepanjang jalan Sungai Sarik ini, dan BPAB juga membantu kegiatan-kegiatan yang ada di nagari jika kegiatan itu minta bantuak kepada pihak BPAB dari segi pendanaanya ...” (Wawancara tanggal 8 September 2021).

Berdasarkan penjelasan dari ibuk sekretaris Wali Nagari Sungai Sarik Lumpo ini terlihat bahwasanya kehadiran BPAB memberikan yang terbaik untuk masyarakat baik itu dari segi pelayanan, kualitas airnya dan bahkan respon cepat yang dilakukanya sangatlah memberikan kepuasan bagi pelangganya serta BPAB ini telah menjadi sebuah aset bagi Nagari Sungai Sarik Lumpo yang patut di banggakan, BPAB telah memberikan manfaat yang begitu besar bagi masyarakat, serta BPAB tidak membebani masyarakat dari segi pembayaranya 
Muklis Muklis, Nora Susilawati Strategi Badan Pengelolaan Air Bersih (BPAB) dalam Mempertahankan Pelanggan Di Nagari Sungai Sarik Lumpo, Kecamatan IV Jurai, Kabupaten Pesisir Selatan

karna, harga dari sumber air bersih ini yang terjangkau oleh masyarakat, serta BPAB sendiri memiliki peran penting tersendiri untuk Nagari Sungai Sarik Lumpo, karena hasil dari penjualan air bersih ini di kembalikan lagi kemasyarakat dalam berbagai bentuk seperti untuk pembangunan masjid, penerangan jalan, bahkan disaat ada kegiatan maka BPAB ikut berkontribusi dari segi pendanaanya.

\section{Eksternal}

\section{Menganggap Pelanggan Sebagai Keluarga}

Dalam hal memberikan layanan, BPAB memberikan layanan kepada pelangganya dengan cara menganggap pelanggannya sebagai keluarga sendiri yang harus dijaga dan di berikan yang terbaik. Menurut nilai kekeluargaan telah mereka dibangun sejak awal berdirinya BPAB. Selain itu, pengurus dibentuk langsung oleh masyarakat secara musyawarah. Dengan demikian pengurus merasa mereka telah diberikan amanah oleh masyarakat untuk mengurus dan mengelola air ini secara sebaik-baiknya, oleh karena itu pengurus menganggap masyarakat sebagai bagian dari keluarga mereka yang harus dilayani dengan baik.

BPAB Sebagai organisasi milik Nagari Sungai Sarik Lumpo dan menjadikan BPAB sebagai aset bagi nagari yang harus dijaga dan dipertahankan dengan sebaik-baiknya, dengan adanya petugas menganggap pelanggan sebagai keluarga maka hubungan baik antara petugas dengan masyarakat sebagai pelangganya memiliki hubungan baik sehingga BPAB ini bisa esksis dan berkebang sampai sekarang.

Dalam hal ini peneliti melalakukan wawancara kepada ketua pengawas BPAB untuk menggali lebih dalam mengenai salah satu strategi BPAB yaitu petugas menganggap pelanggan sebagai keluarga. Bapak Agustiar selaku badan pengawas mengatakan bahwa apabila terjadi kerusakan mengenai pipa, kran ataupun kilometer pada pelanggan dan hal ini akan di urus langsung oleh petugas. Mengenai biayanya pelanggan hanya membayar untuk keperluan pokoknya saja seperti pipa, kran atau kilometernya saja, dan untuk upahnya petugas tidak mematok harga itu tergantung berapa yang di kasih pelanggan bahkah pelanggan hanya mengucapkan terima kasih saja ataupun cuman menawarkan kopi segelas, dan hal itu tidak dipermasalahkan oleh petugas karena petugas telah menganggap pelangganya tersebut sebagai keluarga yang harus di layani dan diberikan yang terbaik. Selanjutnya pembayaran rutin tiap bulan yang harus dikeluarkan oleh pelanggan terhadap perkubiknya air bersih ini. Petugas yang menagih tidak akan memberatkan pelanggan, apabila pelanggan tidak mampu membayar dengan waktu yang telah di tetapkan maka petugas mentoleril ataupun mengasih waktu ke pelanggan untuk membayar dengan alasan-alasan yang jelas.

Berdasarkan wawancara peneliti dengan Bapak Agustiar mengatakan dengan tegas bahwa strategi harus diterapkan untuk mendapatkan hasil yang baik, terutama didalam mengelola sumber air bersih BPAB, sebelum melangkah lebih jauh terlebih dahulu membangun hubungan baik antara anggota pengurus dan setelah itu baru di terapkan kepada masyarakat sebagai pelanggan $\mathrm{BPAB}$, hubungan baik ini akan akan meningkatkan kepercayaan masyarakat dan membuat $\mathrm{BPAB}$ selalu eksis dan berkembang di tengah-tengah masyarakat sebagai penyedia air bersih.

Hal yang senada juga disampaikan oleh pengurus BPAB Nagari Sungai Sarik Lumpo, dan berikut wawancara yang peneliti lakukan kepada Bapak Drs. Jasli pada hari Jumat tanggal 27 Agustus 2021 di rumah beliau. Bertempat di Nagari Sungai Sarik Lumpo pada pukul 14.0015.00 WIB. Wawancara dilakukan diruang tamu rumah subjek. Dalam wawancara ini peneliti 
Muklis Muklis, Nora Susilawati Strategi Badan Pengelolaan Air Bersih (BPAB) dalam Mempertahankan

dibantu oleh seorang teman peneliti yang membantu dalam mengatur dokumentasi. Setelah perkenalan di awal pertemuan, yang mana Bapak Drs. Jasli berumur (60 tahun).

Bapak Drs. Jasli selaku ketua pengurus BPAB Sungai Sarik Lumpo mengatakan bahwa pengurus memberikan yang terbaik untuk pelanggan baik itu dari segi pelayanan ataupun jasa yang diberikan, dan pelayanan itu diberikan kepada pelanggan atas dasar kekeluargaan karena petugas tidak menuntut banyak kepada pelanggan seperti apabila terjadi kerusakan dan kami langsung memperbaiki kerusakan tersebut. Pengurus datang ke lokasi secepat mungkin dan untuk harga pengurus tidak menetapkan berapa yang harus dibayar. Hal itu tergantung berapa yang dikasih oleh pelanggan kepada petugas dan pengurus tidak mempermasalahkan itu karena pelanggan sudah di anggap keluarga sendiri yang harus dilayani dan diberikan yang terbaik.

“...Bapak sebagai ketua pengurus BPAB menyampaikan bahwasanya untuk mempertahankan pelanggan, BPAB harus bisa bersaing dengan PDAM demi mempertahankan pelangganya, maka dari itu BPAB memberikan pelayanan sebaik mungkin demi kepuasan pelangganya, dan BPAB menganggap pelangganya sebagai keluarga sendiri karna BPAB lahir atas kerja sama masyarakat Nagari Sungai Sarik Lumpo dan sekaligus sumber air bersih ini merupakan milik Masyarakat Nagari Sungai Sarik Lumpo, karena telah menjadi keluarga untuk itu BPAB paham dengan perekonomin masyarakat, untuk itu masyarakat diberikan kelonggaran dari segi pembayaran uang bulanan perkubiknya, dan pengurus BPAB sangat dekat dengan masyarakat sekaligun pelanggan BPAB..." (Wawancara Tanggal, 27 Agustus 2021).

Wawancara di atas menjelaskan bahwa perlunya suatu strategi dalam mengelola sumber air bersih BPAB yang bertujuan untuk memberikan kenyamanan dan kepuasan bagi pelanggan yang fokuskan menganggap pelanggan sebagai keluarga sendiri yang harus dilayani dan di berikan yang terbaik. Untuk itu para pengurus yang telah diberi amanah untuk mengelola sumber air bersih BPAB ini telah berhasil menjalankan tugasnya, hal ini dibuktikan dari sejak awal bedirinya BPAB dan sampai sekarang masyarakat Nagari Sungai Sarik Lumpo masih menggunakan BPAB ini sebagai sumber air bersih utama mereka.

\section{Pembahasan}

Setelah peneliti mendapatkan data diatas, maka permasalahan tersebut dapat dianalisis dengan menggunakan teori struktural fugsional (AGIL) yang di kemukakan oleh Talcot Parsons dengan asumsi dasar adalah bahwa setiap struktur dalam sistem sosial adalah fungsional terhadap yang lain. Sebaliknya kalau tidak fungsional maka struktur itu tidak akan ada atau akan hilang dengan sendirinya. Dengan asumsi dasar ini, Parsons percaya bahwa ada empat imperative fungsional yang diperlukan atau menjadi ciri seluruh sistem adaptasi AGIL.

\section{Adaptation (Adaptasi)}

Sistem harus menanggulangi situasi eksternal yang gawat. Sistem harus menyesuaikan diri dengan lingkungan dan menyesuaikan lingkungan itu dengan kebutuhannya atau pemeliharaan pola. Sejak awal berdirinya BPAB hanya bisa mengairi Nagari Sungai Sarik Lumpo karna keterbatasan biaya, namun dengan perkembangannya BPAB mampu mamperluas jangkauannya ke nagari sebelahnya, hal ini tidak akan terlepas dari usaha para pengurus $\mathrm{BPAB}$. Sehingga BPAB mampu beradaptasi serta menyesuikan diri dengan kebutuhan masyarakat. 
Muklis Muklis, Nora Susilawati Strategi Badan Pengelolaan Air Bersih (BPAB) dalam Mempertahankan Pelanggan Di Nagari Sungai Sarik Lumpo, Kecamatan IV Jurai, Kabupaten Pesisir Selatan

Tidak hanya itu BPAB harus mampu beradaptasi terhadap kebutuhan masyarakat yang meningkat seiring perkembangan zaman, untuk menanggapi itu BPAB perlu membuat terobosan-terobosan untuk menunjang terpenuhinya kebutuhan masyarakat ini, seperti pelanggan dari tahun ke tahunya mengalami penambahan. Sehingga debit air yang tersedia harus mampu memenuhi kebutuhan pelanggan tersebut, agar tidak terjadi keluan pada pelanggan. Apabila BPAB mampu mempertahankan bahkan mengembangkan sumber air bersih ini dengan baik maka BPAB sendiri akan selalu eksis di tengah-tengah masyarakat.

\section{Goal Attainment (Pencapaian Tujuan)}

Sebuah sistem harus mencapai dan mendefinisikan tujuan utamanya. Tujuan yang harus dicapai oleh BPAB adalah untuk selalu eksis dan berkembang di tengah-masyarakat, serta memberikan kepuasan terhadap pelayanan yang diberikan oleh BPAB. Untuk mencapai semua ini pengurus $\mathrm{BPAB}$ harus memiliki hubungan baik seperti keluarga dengan masyarakat sebagai pelanggan setianya serta koordinasi baik ditunjukan antara pengurus dengan Masyarakat Nagari Sungi Sarik lumpo demi mencapai sebuah tujuan tersebut.

Pengurus BPAB tidak boleh puas dengan kedaan yang sekrang, karena BPAB harus selalu bisa memberikan perubahan yang mampu membawa BPAB kepada kondisi lebih baik lagi, ini semua bisa tercapai apabila para petugas dan masyarakat secara bersama-sama kompak di dalam membangun dan mengembangkan BPAB ini sehingga tujuan utama BPAB untuk memberikan kepusan kepada pelangganya dapat terlaksana, dan BPAB akan selalu eksis di tengah-tengah masyarakat.

\section{Integration (Integrasi)}

Suatu sistem harus mengatur antar-hubungan bagian-bagian yang menjadi komponennya. Sistem juga harus mengelola antar hubungan ketiga fungsi (A,G,L). Integrasi juga merupakan prasyarat yang berhubungan dengan interelasi antar para anggota dalam sistem sosial. Hubungan baik serta kekompakan antara para pengurus harus bisa dijaga, hal ini akan berpengaruh kepada baiknya di dalam pengelolaan BPAB, serta koordinasi dengan masyarakat Nagari Sungai Sarik Lumpo tetap berjalan sehingga Adaptation, Goal Attainment dan Latency bisa berjalan dengan baik dan BPAB bisa selalu eksis dan berkembang di tengah-tengah masyarakat.

\section{Latency (Latensi)}

Sebuah sistem harus memperlengkapi, memelihara atau memperbaiki, baik motivasi individual maupun pola-pola kultural yang menciptakan dan memompang motivasi (Ridzer, 2007). Dalam kepengurusan ketua harus bisa mengkoordinir anggotanya agar selalu kompak dan memiliki hubungan baik seperti keluarga sendiri, dalam hal ini koordinasi sangat dibutuhkan sesama anggota maupun dengan masyarakat Nagari Sungai Sarik Lumpo.

BPAB merupakan sumber air bersih yang berada di Nagari Sungai Sarik Lumpo, dalam pembangunan $\mathrm{BPAB}$ ini seluruh masyarakat secara swadaya dengan cara kerjasama membangun sumber air bersih ini. Dengan adanya kerjasama ini akan menimbulkan pola-pola kultural yang berbentuk kerjasama antara semua komponen masyarakat yang harus dijaga samapai sekarang.

\section{Kesimpulan}


Muklis Muklis, Nora Susilawati Strategi Badan Pengelolaan Air Bersih (BPAB) dalam Mempertahankan Pelanggan Di Nagari Sungai Sarik Lumpo, Kecamatan IV Jurai, Kabupaten Pesisir Selatan

Berdasarkan penelitian yang telah dilakukan di Nagari Sungai Sarik Lumpo Kecamatan IV Jurai Kabupaten Pesisir Selatan menunjukan bahwa BPAB yang dibangun secara swadaya oleh masyarakat telah menjadi sebuah organisasi kebanggaan masyarakat. Dengan adanya berdirinya BPAB ini memberikan banyak dampak positif bagi masyarakat Nagari Sungai Sarik Lumpo, seperti kemudahan dalam menggunakan sumber air bersih, dan harganyapun tidak memberatkan masyarakat. Nagari Sungai Sarik Lumpo mulai dikenali oleh nagari lain di Kecamatan IV Jurai karena adanya sumber air bersih BPAB ini. Selanjutnya peran penting yang ditunjukan oleh para pengurus BPAB yang tetap menjaga kekompakan antara sesama pengurus serta koordinasi yang baik sehingga terkelola lah dengan baik sumber air bersih BPAB ini, tidak hanya itu masyarakatpun sampai sekarang masih ikut andil demi kemajuan sumber air bersih ini. Sehingga BPAB bisa eksis dan berkembang sampai sekarang.

\section{Daftar Pustaka}

Kornita, S. E., \& Riau, U. (2020). Strategi Pemenuhan Kebutuhan Masyarakat terhadap Air Bersih di Kabupaten Bengkalis The Strategy to the Community Needs for Clean Water in Bengkalis Regency. 11(28), 166-181. https://doi.org/10.33059/jseb.v11i2.1883

Moeleong, J. (2006). Metodelogi Penelitian Kualitatif. Bandung: PT. Remaja Rosdakarya.

Mubarok, N. (2017). Strategi pemasaran islami dalam meningkatkan penjualan pada butik calista. 3(1), 73-92.

Novita. (2017). Analisis Dan Formulasi Strategi Ketersediaan Air Bersih Di Lokasi Transmigrasi ( Studi Kasus: Kacamatan Lasalimu Selatan Kabupaten Buton ) Analysis And Strategy Formulation For Clean Water Availability In Transmigration Area ( A. 7(2), 114-121. https://doi.org/10.19081/jps1.2017.7.2.114

Nurrohman, T.. (2015). Respon Mahasiswa Dakwah Terhadap Siaran Radio Komunitas Star FM IAIN Purwokerto. Skripsi. IAIN Purwokerto

Ridzer, G. (2007). Teori Sosiologi Modern. Jakarta: Kencana Prenada Group.

Simanjuntak, S., Zai, E. O., \& Sihombing, P. O. (2020). Analisa Kebutuhan Air Bersih Pada di KotaBinjaiSumateraUtara.JurnalVisiEksakta,1(1),123-141.

Sugiarto, F. F., Bisnis, P. M., Manajemen, P. S., Petra, U. K., Siwalankerto, J., \& Pendahuluan, I. (2016). Analisa Strategi Bersaing PT . Surya Cipta Mandiri. 4(2), 250-258.

Sugiyono, S. (2007). Penelitian Kuantitif, Kualitatif Dan R\&D. Bandung: Alfabeta.

Winarno, T. (2011). Studi Penentuan Prioritas Strategi Pengelolaan Air Tanah Di Kota Jayapura. Prosiding Seminar Nasional Manajemen Teknologi XIII 